\title{
LEVEL OF EDUCATION AND TAX COMPLIANCE FULLFILMENT: EVIDENCE FROM DUDUK SAMPEYAN, GRESIK, EAST JAVA INDONESIA
}

\author{
Maria Tambunan ${ }^{1}$, Indriani $^{2}$ \\ \{maria.tambunan@ui.ac.id ${ }^{1}$, indri4mf@gmail.com² \} \\ Faculty of Administrative Science, Universitas Indonesia, Indonesia ${ }^{1}$, Faculty of Administrative Science, Universitas \\ Indonesia, Indonesia ${ }^{2}$
}

\begin{abstract}
This study analyze implementation of tax compliance performed by the village apparatus in Duduk Sampeyan Districts for transactions relating the use of village funds and the challenges faced to fulfil those obligations. This study uses a qualitative approach. The results show cause of the low compliance of village treasurers with low level of education, which correlated with the low understanding of tax knowledge. The village officials had worked to the same steady pattern over a long period of time. The existence of new obligations in the form of tax administration is a challenge and become additional responsibility. The low level of compliance is not borne out of a desire to deliberately avoid paying taxes. The assistance process, which was designed to increase taxation knowledge in order to be able to carry out tax obligations as stipulated in the applicable taxation provisions need for adequate facilities and infrastructure, sufficient resources, and followup.
\end{abstract}

Keywords: compliance, tax administration, tax procedures, tax knowledge.

\section{Introduction}

The idea of undertaking development in Indonesian by strengthening the capacity of the Village, known as "Building Indonesia from the Edge," is a concrete form of equitable welfare by placing villages as the spearhead of development. Every year the Central Government allocates a fairly large Village Fund; in 2015 this amounted to a total of IDR. 20.7 trillion, while on average, each village received an allocation of IDR. 280 million. In 2016 this increased to IDR. 46.98 trillion and an average of IDR. 628 million, and in 2017 it rose further to IDR. 60 trillion with an average of IDR. 800 million $^{1}$. Based on a survey conducted by the Ministry of Finance rin the last three years, the Village Fund has resulted in infrastructure and facilities that make it easier for rural communities to carry out their activities. The results of evaluations on the use of the Village Fund over the past two years show that it has succeeded in improving the quality of life of rural communities, as indicated by a decrease in the level of rural inequality from 0.34 in 2014 to 0.32 in 2017 . There has also been a decline in the number of rural poor, from $14.09 \%$ in 2015 to $13.93 \%$ in 2017 . Of course, the use of village funds sourced from State Budget (APBN) must be based on the principles of transparency, accountability, and administrative disciplined following the prevailing provision. However, various obstacles were encountered in the distribution and use of village funds. Some of the common obstacles faced by village governments include (i) the use of funds outside the priority area, (ii) expenditure is not supported by evidence (iii) work is carried out by third parties, (iv) the implementation of tax obligations is not in accordance with the provisions, (v) villages are not familiar with the mechanism of money supply, and (vi) spending outside the budget.

The provisions regarding taxation are also an important concern, wherein Article 31 of Law no. 6 of 2014 on Villages [1] states that "Village Treasurers as required to collect Income Tax (PPh) and other taxes, they are required to deposit all taxes collected to the state treasury account in accordance with statutory provisions." It is not an easy job complying with the provisions relating to the obligations of the Village Head to carry out tax obligations in the form of calculating tax payable, withholding income tax and depositing it to the government through a state treasury account, followed by the subsequent reporting of taxes that have been deposited with several types of Income Tax Return (SPT). The village treasurer duty resembles the duty of the state treasurer, who manages the State Budget. It is thus a role that is related to fulfilling tax obligations. Due to the various tax provisions, which are considered quite complicated, especially for conducting transactions, it is common for village treasurers to experience confusion. In fact, many do not understand the provisions in terms of the tax obligations arising when a transaction is carried out and how to resolve these obligations. The areas used as the location of this study were villages in the district of Duduk Sampeyan, Gresik district, East Java province. This study aims to analyze the knowledge of village apparatus taxation in Duduk Sampeyan District and the challenges faced in carrying out tax obligations on the use of village funds. This study also aims to provide input related to improving tax compliance in the future.

\section{Literature Review}

${ }^{1} 1 \mathrm{USD}=14.500 \mathrm{IDR}$. 
In various discourse, tax compliance is the most neutral term used to describe the relationship between taxpayers and tax authorities [2] and where the term is not associated with anything unlawful [3]. The commonly recognized meaning of compliance by practitioners and academics in the context of tax compliance relates to the reporting of all income and depositing the amount of tax payable in accordance with applicable regulations [4]. From another perspective, compliance is a form of "game-playing" in which taxpayers adjust their behavior based on whether there is a gap and in order to avoid taxes or the fulfillment of tax obligations solely to avoid penalties that will entail them having to pay more tax [5]. Moreover, in certain cases, non-compliance results from a taxpayer's negative perception of the tax authority [6].

Internal Revenue Services adopt the definition by [7] wherein tax compliance is the behavior of taxpayers who fill out reporting letters correctly, accurately, in accordance with the specified time, and pay the tax due according to the provisions without the need to be issued with a warning from the tax authority [7]. In reality, however, tax compliance can be viewed from two different perspectives, namely the conceptual perspective and the implementation perspective. The conceptual perspective emphasizes the desire of taxpayers to comply with the applicable provisions without implementation, while from the implementation perspective, compliance is seen as the effort to fulfill various tax obligations [6]. Tax compliance behavior is different from motivational compliance. In general, the motivation to comply or not comply is driven by a desire to be obedient/non-compliant and this comes from oneself. This type of behavior can include aggressive tax minimization, which results in the tax authority having to work to build compliance management. In addition, there is traditional non-compliance; for example, an inability to fulfill basic tax obligations such as calculating the amount of tax payable and filing tax returns to the extent that it is considered to be tax avoidance behavior [8].

The behavior to comply with tax obligation can be related to the level of tax knowledge and level of education. The compliance among people which has been exposed to general tax education and tax compliance practices tend to affect the significant improved behavior [9]. The attempt to increase the tax compliance should be undertaken by the tax authority could not rely on tax audit task as a mode of enforcement, instead it needs to invest on the program which be able to bring the people to comply with the taxation system. Continuous enforcement through tax audit and investigation besides it must not the main strategy to make people comply, it also would cost the tax administration while the tax administration has to run its activities with limited resources. Prior to improving the compliance behavior, the increasing of tax knowledge through various followed-up program can help to improve the compliance, given that the tax compliance depends on an understanding of relevant tax laws and other related regulation. Subsequently, the level of tax knowledge and the understanding to the prevailing rules in a state correlates with the number of years spending on education. Therefore, it would not be surprising if the taxpayer with low level of education tend to have poor tax knowledge.

\section{Methodology and Data Analysis}

This study uses a qualitative research approach. This approach involves exploring and identifying the meaning of something that is considered by a number of individuals or groups to originate from social or humanitarian problems. The data collection techniques involved the collection of both primary and secondary data. Primary data comprise data or information obtained by researchers directly from informants or research participants or through field observations. The primary data in this study were obtained by distributing questionnaires to all village officials in the Duduk Sampeyan District as well as through in-dept interviews with various parties comprising the Village Officials, the District Officials, and the Tax Office Public Relations staff in charge of Duduk Sampeyan District. The in-dept interviews were undertaken to obtain the robust information how they completed their tax obligation as complement to the filled-out questionnaire. For secondary data, meanwhile, consist of data that are not obtained by researchers directly but rather are processed data in the form of literature studies that are then used to produce additional information aimed at complementing the primary data. Qualitative data analysis techniques were employed, whereby the raw data obtained from field studies and literature were analyzed by sorting and looking for similar patterns related to themes, with the things that would eventually be found used in learning and in analyzing problems related to the research themes. Through these data collecting method, it is expected it could portray the level of compliance, level of knowledge and how the government can create the strategy to fill the gap of knowledge and to improve the level of voluntary tax compliance.

\section{Research Result and Discussion}

The process of ensuring compliance is part of the implementation of services (public service) and is not only limited to the delivery of documents to the government after going through a series of procedures. From the traditional perspective, when the Income Tax Returns and related documents are submitted as part of the taxpayer's responsibility, the next step is the obligation of the authority to audit the SPT and identify whether there are any errors, such as a mechanization process of making goods. The compliance process should be seen as a value in which the process of fulfilling these obligations is a series of services in which there is engagement between the service provider and the service recipient, and not merely as a type of delivery of goods in the form 
of documents. The type of common transaction undertaken by the villages apparatus is depict by the following table 1 .

Table 1. Collection of Article 21 Income Tax by the Village Treasurer

\begin{tabular}{ll}
\hline Transaction Type & Types of tax withheld from the generated income \\
\hline Payment of committee fees, procurement officials, & Class IV - 15\% \\
project supervision activities and village & Class III - 5\% \\
development projects (if they are civil servants) & Class II and I - 0\%
\end{tabular}

Payment of honorariums for committee members or other activities related to activities in villages that are not civil servants

\begin{abstract}
Wages for casual workers who generally receive income in the form of wages calculated based on the implementation of daily work, weekly or piece of work in a particular project
\end{abstract}

Wages of non-civil servant experts

\author{
Article 17 Income Tax rates progressive \\ $0-50 \mathrm{M}=5 \%$ \\ $50 \mathrm{M}-250 \mathrm{M}=15 \%$ \\ $250 \mathrm{M}-500 \mathrm{M}=25 \%$ \\ Above $500 \mathrm{M}=30 \%$ \\ *) in IDR Currency
}

Withholding Income Tax Article 21 (Income Tax for employees) as long as the income received does not exceed the limit of Non-Taxable Income.

The provisions that have been in effect since 2016 state that the limit of non-taxable income per day is IDR. 450,000/per day and if accumulated does not exceed IDR. 4,500,000 in one month.

The calculation follows the provisions ..... namely $50 \% \mathrm{x}$ progressive tariffs of Article $17 \mathrm{x}$ the number of wages paid.

\section{Source: [10]-[12], processed by researchers.}

In addition to the obligation to collect Article 21 Income Tax, the Village Treasurer is responsible for collecting Article 22 Income Tax amounting to $1.5 \%$ of the transaction value on the purchase of goods with a value in excess of IDR. 2,000,000 for uninterrupted purchases. If the transaction is with a trader who does not have an NPWP, then a rate $100 \%$ higher than the basic tariff of Article 22 Income Tax is applied, that is, 3\%. In addition, it is possible to deduct Article 23 Income Tax from income received by treasurer transaction partners for interest, dividends, royalties, gifts, and rents (excluding rental of land and/or buildings) as well as fees for engineering, management services, and consulting services, more details of which are given in Minister of Finance Regulation No. 141/PMK.03/2015. However, the tax aspect related to transactions carried out by the Village Treasurer is in the form of rent and services. The transaction is subject to a tax of $2 \%$. If the transaction is conducted with a trader who does not have an NPWP, a rate of $100 \%$ higher than the base rate of Article 23 Income Tax will be charged, which is $4 \%$. Furthermore, the treasurer is obliged to collect VAT from third parties on the purchase of taxable goods/services. There are also various possibilities of transactions with more complex variations according to the development needs in each village and the circumstances in which the transactions are carried out. This article is not intended to discuss the tax aspects of each transaction made but instead, it considers the fulfillment of tax obligations. The following section provides an explanation of the fulfillment of tax obligations concerning the use of village funds in Duduk Sampeyan District, Gresik, East Java. To deposit tax withheld/collected to the Bank/post office and report to the relevant Tax Office (KPP).

\section{Discussion}

1. Fulfillment of Tax Obligations for the Use of Village Funds in Gresik, East Java

[13] and [14] stated in relation to compliance that, basically, compliance and non-compliance are based on internal factors of taxpayers, which further, it may be correlated to the level of tax knowledge [9]. Based on the survey of 47 village apparatuses consisting of Treasurers and Village Secretaries (hereinafter referred to as village officials) in Duduk Sampeyan District, it was found that the treasurer essentially had difficulty fulfilling tax obligations. This difficulty was due to low level of education of village officials, which served as the source of their difficulty in increasing compliance of tax obligation fulfilment on the village funds they managed. On their perception, it is quite complicated to meet the tax obligations, although it cannot be denied that the tax provisions as described in the previous chapter are not simple as reflected in the following diagram. This behavior justify that the compliance has certain extend to the level of people knowledge.

There are a relatively large number of tax filing obligations and the tax provisions are considered complicated because each transaction has its own rules, meaning each one poses its own challenges. However, on 
the other hand, based on the survey data acquired, it should be noted that government bureaucracy is not perceived as being a hugely complicated matter. Looking more deeply into assistance provided by the government, most of the village treasurers reported that they had no experience of assistance up to the point at which the survey was carried out. Those that reported they had received assistance and had not yet received assistance are further described in the next section since each village was in the same district, where each village received the same treatment. The proportion who had benefited from some mentoring was very small. This is illustrated in the following diagram.

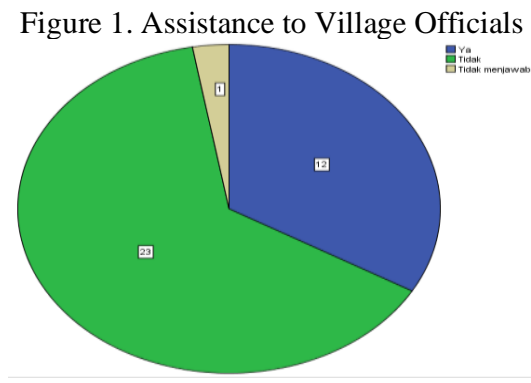

Source: Primary data gathered through questionnaire (2019), processed by the researchers (blue for yes, green for no, grey for no answer)

Furthermore, related to the experience of mentoring obtained by the village officials, most of them had only experienced one instance while a few had received up to four instances of assistance as village officials took part in implementing tax obligations. This is illustrated in the following diagram.

Figure 2. Frequency of Assistance/Training that Had Been Followed

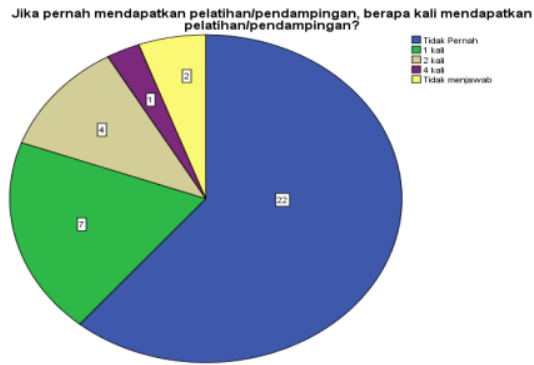

Source: Primary data gathered through questionnaire (2019), processed by the researchers

From the informants with whom a survey was conducted on the agencies that had provided assistance, the agencies from government body that provided training activities included BPKAD, KPP Pratama Gresik, Gresik Regional Government, the Head of the Gresik Regency Development Section, and district extension workers. Based on this information, at least five training sessions had been conducted on the fulfillment of tax obligations. However, this had proven adequate to increase the understanding of village officials. From the above figures, it can be temporarily concluded that an important factor related to the difficulty of increasing tax compliance among village officials is the low level of taxation knowledge.

2. Implementation and Challenges in the Implementation of Fulfillment of Taxation Obligations in Duduk Sampeyan

Most of the village officials in Duduk Sampeyan have a high school education and carry out their work according to an old and steady system and pattern. In a sense, the obligation to record, report, and carry out other duties related to accountability and transparency in the use of the budget are seems the new things. The existence of these collection obligations cannot be responded to equally by every village official in accordance with the mandate of the regulation. This is a result of the education gap, which is quite wide, combined with the fairly stable work pattern established many years before the system of accountability and transparency came into force. In terms of adapting to the new system, most of the village officials were not yet familiar with administrative orders. In various studies related to the impact of increasing taxation knowledge on compliance, a correlation tended to be shown between compliant behavior and the level of implementation of tax obligations.

Having acquired the basic understanding of tax knowledge such as; why it is necessary to pay taxes, why a transaction is taxed, and what type of tax relates to the transaction should at least encourage taxpayers or the agents that it is not so difficult to carry out their obligations [15]. At the time when the Village Fund program was initially formed and the village apparatus received funding from the APBN/APBD, the apparatus remained unaware that tied to the use of these funds was an inherent obligation in the form of tax to be collected on the 
transactions entered into. It means this program has been run even in the absence of basic understanding should be acquired by the village officials. Village officials then recognized this obligation when the higher hierarchy institution conducted an inspection on the use of the funds. When the inspection activities were carried out, the village officials were notified of the obligation to collect VAT and income tax. However, the party conducting the inspection was unable to provide in-depth training on technical matters due to the nature of the inspection activity. It should be emphasized that the inspection served as a starting point from which the village officials were required to know the relevant regulations. Therefore, it can be said that the inspection was the starting point for the establishment of tax awareness and the initiation to establish basic tax knowledge among the village officials. Such tax awareness was formed through the process of a two-way dialogue between the government, in this case the inspectorate, and the village officials [16], [17].

On the sound more positive vibe, this finding then has created new awareness that the village officials had an important role to play in the process of raising funds and paying them back to the country. Seeing the need to maintain and increase awareness, relevant government departments, including the Directorate General of Taxes have a duty to provide socialization and assistance. The existence of this awareness therefore serves as evidence that non-compliance is not based on a motivation to avoid taxes or simply violate the applicable regulations but it may sufficiently to justify that the failure to comply the tax obligation was due to lack of sufficient knowledge should be owned by the mandated person.

It is not an easy process for either the parties that deliver taxation material or village officials to improve their understanding and learn the tax assessment provisions. The providers of training are expected to be adept at talking in public, which although not as serious as delivering taxation material on common formal training, does require trainers to deliver the training material in a simple way without reducing its essence. After several trainings made with formal arrangement, the participants did not yet know well on how to apply the appropriate rates of Income Tax or VAT correctly following the prevailing rule into each transaction made. Explanations regarding the basic provisions governing the types of tariffs have proven that such method of training was still insufficient to aid the increase level of understanding of village officials. What is more, technical practices are extremely needed besides simply verbal explanation on how the rule implemented into each transaction, then the simulations of everyday transactions should be conducted repeatedly, to include the transaction being carried out, the type of tax associated with the transaction, the rates used, the amount of tax withheld/collected, proof of the required cut, practice in filling in the required pieces of evidence, and the submission of tax returns based on the reporting schedule. If there are changes to taxation rules, new challenges will arise because the absence of fundamental concept on levying taxes.

The picture is very different among the small number of treasurers who have graduated with an undergraduate education and who are still relatively young. With adequate education, a treasurer has the desire to seek information from various media related to the provisions relating to tax obligations even if he does not really know whether the work being carried out is correct. However, for this step, the treasurer has strived to carry out his tax obligations despite the fact that it was driven by a reprimand or even sanctions from the relevant parties. Those treasurers who do not have qualifications pertaining to the role of the treasurer (i.e., those who constitute the majority group, with an education level up to high school, and over 40 years of age) tend to leave the matter to younger village officials in terms of them seeking information or asking for help from other village officials who are considered to be better informed. It is really understood that such practices are not fair, however it is a strategy chosen by the village apparatus to avoid the sanction or simply to complete their obligation.

Related to the socialization carried out by various government agencies, the district apparatus that monitor the work of the village officials assumed that there is a relatively low level of demand for the socialization provided by the Directorate General of Taxes through the Gresik Tax Service Office (KPP) on the part of the village officials. This was caused by the KPP not covering the transportation costs associated with attending the socialization and the village officials having to travel a considerable distance to the location of the socialization, which would entail them leaving their daily work. It is not common practice for the tax offices to cover the costs of attendance for every training participant since every use of the budget must be based on a framework of applicable provisions. In general, the village apparatus has other work besides managing the village because the income they derive from their position as the village apparatus is insufficient to meet the needs of the family. Then, the honorarium received as the person who responsible to do village management to village officials is based on their level of education. If their level of education is inadequate high, they will receive only a very low level of compensation with respect to their work in dealing with administrative matters related to village government activities. Leaving the village and work solely to take part in socialization with no form of direct compensation was not an option for the village officials.

Basically, the government concerned, notably the Directorate General of Taxes, through the Tax Service Office, conducts socialization to village officials several times a year. In addition, the Gresik district government carried out socialization activities on the same topic. However, the combination of the low level of education and the new knowledge being presented, which is classed as complicated, creates an obstacle for both those who are given the counseling and those who provide the education. As part of its socialization effort, village treasurers 
make up one of the groups targeted by the tax offices. It has compiled a work program related to increasing both knowledge and treasurer compliance and has prepared extension workers to run the program. For this activity, the tax office has strived to achieve a target level of compliance; however, it has not been able to quantify the level of success of the socialization on an average scale because of the relatively high gap and the variation in the capacity of the village officials.

In the counseling process, on the one hand, the extension workers have endeavored to understand the difficulties and problems faced by treasurers and to provide assistance related to fulfilling tax obligations. On the other hand, however, after repeated counseling, the tax office has also begun to introduce a reward and punishment process for the implementation of these tax obligations. The type of enforcement action that would be enacted by the tax office consists of making a summons, delivering a reprimand, followed by a decree. The existence of these enforcement actions has a deterrent effect on the treasurer who has been called/reprimanded and the goal is to ensure that in the next period, they perform better in terms of the fulfillment of tax obligations. In addition, the effect of enforcement on certain village treasurers leads to an improvement of the behavior of other treasurers, wherein the other treasurers attempt to perform better in carrying out the collection obligations and try to deliver on time. Following this process of knowledge transfer, the existence of enforcement measures is both appropriate and effective [18]. With the summons from the tax office, the treasurers alter their prior behavior in relation to fulfilling tax obligations [19].

\section{Summary}

The pattern of increasing compliance seen in relation to village officials emphasizes changes in the fundamental factors related to compliance, namely the lack of taxation knowledge. However, the other underlying factor is the village officials' low level of taxation knowledge. This is attributable solely to the low level of education of most village officials and correlates with the limited understanding of tax knowledge. The lack of compliance by the Duduk Sampeyan village apparatus was not solely due to a desire to avoid paying taxes or other economic motives aimed at increasing their income. In addition, the village officials have worked according to a steady pattern for a long period of time. The existence of new obligations in the form of the implementation of tax administration, which is not a simple matter, presents a challenge in itself in terms of the need to form a new work pattern. The low level of compliance is not borne out of a desire to violate the applicable regulations. However, the assistance process for increasing tax knowledge in order to be able to carry out tax obligations as stipulated in the applicable taxation provisions is also not easy because of the need for adequate facilities and infrastructure, sufficient resources, and continuous follow-up, including law enforcement.

\section{Implications / Limitations And Suggestions For Further Research}

A final relatively narrow but important question that we identified after data collection had finished, more methodological work is needed on how to robustly capture the impact and outcomes of public involvement in research.

\section{References}

[1] Law no. 6 of 2014 on Villages. The Republic of Indonesia, 2014.

[2] S. B. Long and J. A. Swingen, "Taxpayer compliance: Setting new agendas for research," Law Soc. Rev., vol. 25, no. 3, pp. 637-684, 1991.

[3] E. Kirchler, S. Muehlbacher, B. Kastlunger, and I. Wahl, "Why pay taxes? A review of tax compliance decisions," in Developing Alternative Frameworks for Explaining Tax Compliance, J. Alm, J. MartinezVazquez, and B. Torgler, Eds. Oxon: Routledge, 2010, pp. 15-32.

[4] J. Alm, "A perspective on the experimental analysis of taxpayer reporting," Account. Rev., vol. 66, no. 3, pp. 577-593, 1991.

[5] V. Braithwaite, M. Reinhart, and J. McCrae, "Game playing with tax law," Cent. Tax Syst. Integr. - Res. Note 8, pp. 1-13, 2019, [Online]. Available: http://hdl.handle.net/1885/155621.

[6] A. Rosid, C. Evans, and B. Tran-Nam, "Tax non-compliance and perceptions of corruption: Policy implications for developing countries," Bull. Indones. Econ. Stud., vol. 54, no. 1, pp. 25-60, 2018, doi: 10.1080/00074918.2017.1364349.

[7] B. R. Jackson and V. C. Milliron, "Tax compliance research: Findings, problems, and prospects," J. Account. Lit., vol. 5, no. 1, pp. 125-165, 1986.

[8] V. Braithwaite, "A new approach to tax compliance," in Taxing Democracy: Understanding Tax Avoidance and Evasion, V. Braithwaite, Ed. Hants: Ashgate Publishing Ltd, 2002, pp. 1-11.

[9] R. M. K. Wong and A. W.-Y. Lo, "Can education improve tax compliance? Evidence from different forms of tax education Hong Kong Institute of Business Studies," HKIBS Work. Pap. Ser. 074-1415, pp. 1-38, 2015.

[10] Regulation of the Directorate General of Taxes no. PER/16/PJ/2016 on Technical Guidelines on the 
Procedures for the Withholding, Payment, and Reporting of Article 21 Income Tax and Article 26 Income Tax in Relation to Works, Services, and Activities of Individual Persons. The Republic of Indonesia, 2016.

[11] Regulation of the Minister of Finance no. 262/PMK.03/2010 on Procedure for Withholding Article 21 Income Tax for State Officials, Civil Servants, Members of the Armed Forces, Members of the Police, and Retirees for Income Burdened by the State or Regional Budget. The Republic of Indonesia, 2010.

[12] Regulation of the Minister of Finance no. 101/PMK.010/2016 on Adjustment of Non-Taxable Income. The Republic of Indonesia, 2016.

[13] V. Braithwaite, "Dancing with tax authorities: Motivational postures and non-compliant actions," in Taxing Democracy: Understanding Tax Avoidance and Evasion, V. Braithwaite, Ed. Hants: Ashgate Publishing Ltd, 2002, pp. 15-40.

[14] OECD, Tax Compliance by Design: Achieving Improved SME Tax Compliance by Adopting a System Perspective. Paris: OECD Publishing, 2014.

[15] W. Newman and M. Nokhu, "Evaluating the impact of tax knowledge on tax compliance among small medium enterprises in a developing country," Acad. Account. Financ. Stud. J., vol. 22, no. 6, 2018, [Online]. Available: https://www.abacademies.org/articles/evaluating-the-impact-of-tax-knowledge-ontax-compliance-among-small-medium-enterprises-in-a-developing-country-7649.html.

[16] C. Bennett, "Creating taxpayer awareness: Corporate social responsibility and the forums for taxpayertax administration dialogue," in 45th CIAT General Assembly: Tax Morale as Determining Factor in Improving the Effectiveness of the Tax Administration, 2011, pp. 303-322, [Online]. Available: https://www.ciat.org/Biblioteca/AsambleasGenerales/2011/Ingles/2011_topic_2.3_canada_Bennett.pdf.

[17] A. Nurkhin, I. Novanty, Muhsin, and Sumiadji, "The influence of tax understanding, tax awareness and tax amnesty toward taxpayer compliance," J. Keuang. dan Perbank., vol. 22, no. 2, pp. 240-255, 2018, doi: $10.26905 /$ jkdp.v22i2.1678.

[18] I. P. F. D. Putra and A. Firmansyah, "The effect of tax knowledge reward and enforcement strategies on SMEs tax compliance behavior," in The 7th International Conference on Advances in Social Science, Management and Human Behaviour - SMHB 2018, 2018, pp. 21-28, doi: 10.15224/978-1-63248-160-322.

[19] V. Braithwaite, M. Reinhart, and J. Mccrae, "What are the differences between those who have contact with the ATO and those who do not?," Cent. Tax Syst. Integr. - Res. Note 2, pp. 1-6, 2003, [Online]. Available: http://digitalcollections.anu.edu.au/handle/1885/42099. 